\title{
Facts About Magnesium ${ }^{1}$
}

\author{
Linda B. Bobroff and Jennifer Hillan²
}

\section{Why Do We Need Magnesium?}

Magnesium is a mineral needed by every cell in the body. More than 300 chemical reactions in the body require magnesium. Magnesium helps to:

- support normal muscle and nerve function;

- keep a steady heartbeat;

- keep bones strong;

- make protein and DNA; and

- use energy from the foods we eat.

\section{What Happens If We Don't Get Enough Magnesium?}

Many Americans don't get enough magnesium in their diets. But most healthy people do not have signs of deficiency even if their intake is low because the body stores this mineral. However, people who abuse alcohol, take certain diuretic drugs, or have kidney disease may be at risk for magnesium deficiency. Long-lasting diarrhea or vomiting also can cause a deficiency. Older adults often do not get enough magnesium in their diets.

The following conditions can be signs of magnesium deficiency or other medical problems. Check with your doctor if you have:

- loss of appetite;

- confusion;
- abnormal heartbeat;

- muscle cramps;

- high blood pressure; or

- seizures.

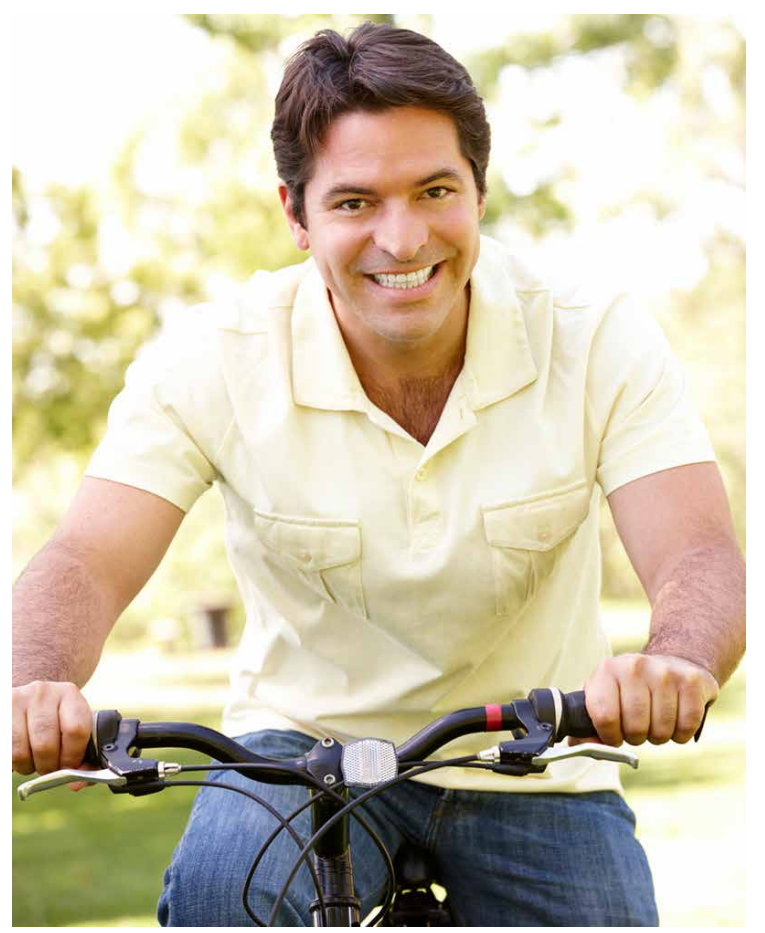

Figure 1. Every cell in your body needs magnesium, so it is important to get enough in your diet.

Credits: iStockphoto

1. This document is FCS8810, one of a series of the Department of Family, Youth and Community Sciences, UF/IFAS Extension. Original publication date: April 2009. Latest revision: July 2013. Please visit the EDIS website at http://edis.ifas.ufl.edu.

2. Linda B. Bobroff, PhD, RD, LD/N, professor, Department of Family, Youth and Community Sciences; and Jennifer Hillan, MSH, RD, LD/N, former ENAFS nutrition educator; UF/IFAS Extension, Gainesville FL 32611. 


\section{How Much Magnesium Do We Need?}

Table 1. Recommended daily intakes of magnesium

\begin{tabular}{|l|c|}
\hline \multicolumn{1}{|c|}{ Life Stage } & $\begin{array}{c}\text { Amount } \\
\text { (mg/day) }\end{array}$ \\
\hline Men, ages 19-30 & 400 \\
\hline Men, ages 31+ & 420 \\
\hline Women, ages 19-30 & 310 \\
\hline Women, ages 31+ & 320 \\
\hline Pregnancy, ages 19-30 & 350 \\
\hline Pregnancy, ages 31+ & 360 \\
\hline Breastfeeding, ages 19-30 & 310 \\
\hline Breastfeeding, ages 31+ & 320 \\
\hline mg = milligrams of magnesium & \\
\hline
\end{tabular}

\section{How Can We Get Enough Magnesium?}

The best sources of magnesium are nuts, legumes, seeds, dark green vegetables, seafood, and whole grains. We can get enough magnesium by eating a variety of these foods every day. Some sources of "hard" water add magnesium to the diet.

Table 2. Food sources of magnesium

\begin{tabular}{|l|c|}
\hline \multicolumn{1}{|c|}{ Food } & $\begin{array}{c}\text { Magnesium* } \\
\text { (mg/serving) }\end{array}$ \\
\hline Sesame seeds, toasted, 1 ounce & 100 \\
\hline Almonds, roasted, 1 ounce & 80 \\
\hline Avocado, Florida, 1 medium & 75 \\
\hline Spinach, cooked, $1 / 2$ cup & 75 \\
\hline Wheat germ, $1 / 4$ cup & 70 \\
\hline Oatmeal, cooked, 1 cup & 65 \\
\hline 100\% bran flakes cereal, 3 /4 cup & 65 \\
\hline Black beans, cooked, $1 / 2$ cup & 60 \\
\hline Potato, baked, with skin, 1 medium & 50 \\
\hline Peanuts, dry roasted, 1 ounce & 50 \\
\hline Whole-wheat bread, 2 slices & 45 \\
\hline Figs, dried, 5 & 30 \\
\hline Banana, medium & 30 \\
\hline Halibut, cooked, 3 ounces & 25 \\
\hline $\begin{array}{l}\text { mg = milligrams of magnesium } \\
\text { * USDA, Agricultural Research Service, National Research Library, } \\
\text { http://ndb.nal.usda.gov/ndb/search/list }\end{array}$ \\
\hline
\end{tabular}

\section{What About Supplements?}

People who eat a variety of healthy foods generally don't need magnesium supplements. However, people who have certain diseases or take certain medications may need extra magnesium. Your health care provider can tell you if you need to take a magnesium supplement.

\section{How Much Is Too Much?}

Magnesium is found in a number of over-the-counter drugs, including "milk of magnesia" and some antacids. Large doses of these products or magnesium supplements can cause nausea, diarrhea, and stomach cramps. Magnesium from foods does not cause these symptoms. You should not get more than $350 \mathrm{mg}$ of magnesium per day from supplements or drugs.

\section{Where Can I Find More Information?}

The Family and Consumer Sciences (FCS) agent at your local UF/IFAS Extension office may have more information or nutrition classes for you to attend (find your local office at http://solutionsforyourlife.ufl.edu/map). Also, a registered dietitian $(\mathrm{RD})$ can provide reliable information.

The following websites also have reliable information:

- Nutrition.gov - http://www.nutrition.gov

- National Institutes of Health, Office of Dietary Supplements - http://ods.od.nih.gov/

- Medline Plus - http://www.nlm.nih.gov/medlineplus/ minerals.html

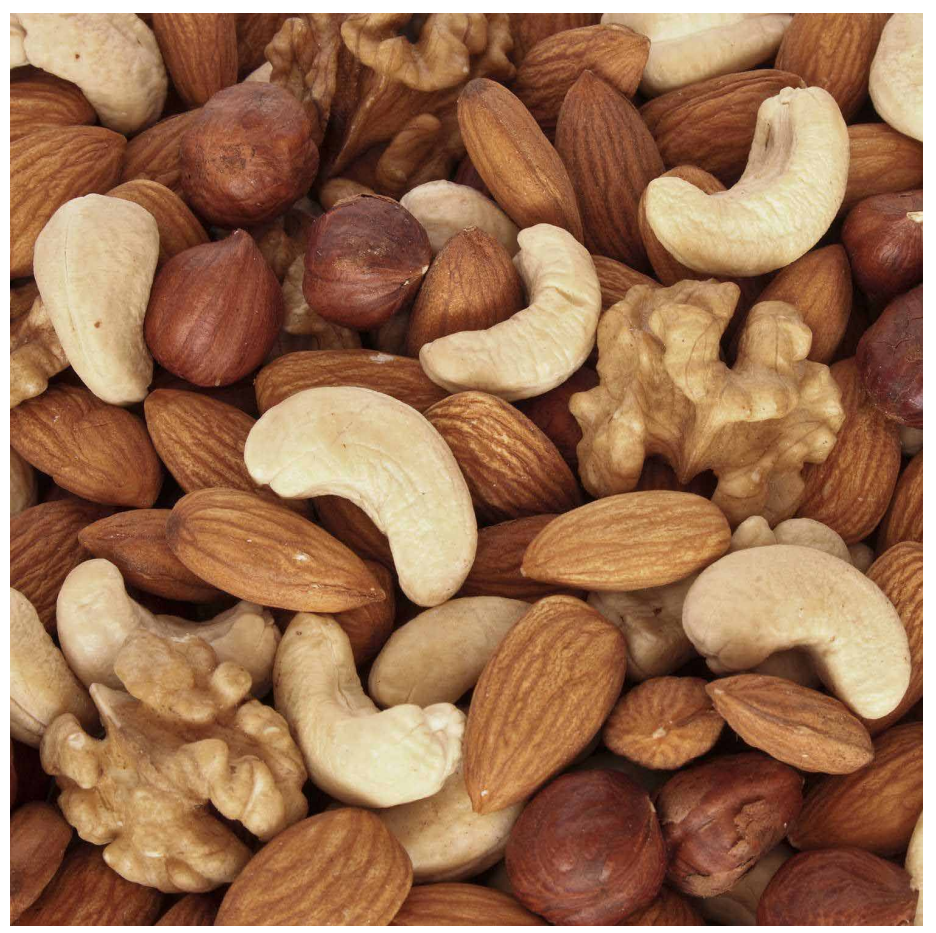

Figure 2. Nuts such as almonds and cashews are good sources of magnesium.

Credits: iStockphoto 